\title{
Camel Milk Consumption Pattern and Its Association with Diabetes among Raika Community of Jodhpur District of Rajasthan
}

\author{
Madhu B. Singh, Ranjana Fotedar and J. Lakshminarayana \\ Desert Medicine Research Centre, New Pali Road, Jodhpur 342 005, Rajasthan, India
}

KEYWORDS Camel; diabetes; milk; desert; Rajasthan

\begin{abstract}
Raika community (OBC) in Jodhpur district is commonly known for keeping camels and might have been consuming camel milk in their diet. It is reported in literature that camel milk consumption may be responsible for reduction of the occurrence of Diabetes in the Raika community which is researchable issue. With this aim present study was conducted in Raika community comprising of 258 individuals from two villages viz. Mongra and Bhatinda of Jodhpur district, Rajasthan. The data was collected for demographic and general information regarding possession of camel along with the usage of camel milk and diabetes. Nearly 27 percent of the Raika community kept She camel but consumption of camel milk by the Raika community was less (18.6\%) and consuming low quantity. No individual was found to be suffering from Diabetes whether they were consuming or not consuming camel milk and observed almost negligible $(0.6 \%)$ symptoms of diabetes i.e. polyurea, polydepsia and polypepsia. Still there is a dilemma demanding more research work in this direction.
\end{abstract}

\section{INTRODUCTION}

Nutrition plays a vital role in the health of a community especially malnutrition. Malnourished populations are more susceptible to most infections and severity of illness worsening the mortality rates (WHO, 1999). Raika community (OBC) in Jodhpur district is commonly known for keeping camels and might have been consuming camel milk in their diet. As reported in literature that camel milk consumption may be responsible for reduction of the occurrence of Diabetes in the Raika community (Agarwal, 2003 and Breitling et al., 2002). It is researchable issue which needs to be explored. With this aim present study has been designed to determine the pattern of camel milk consumption in Raika community and to observe the prevalence of chronic disease with special reference to diabetes.

\section{MATERIALS AND METHODS}

Study Design: A Cross sectional survey was carried out among Raika community.

Sample Size: Population of Raika community in two villages was 200 households. Mongra and

Corresponding author: Dr. Madhu B. Singh

Deputy Director, Division of Nutrition, Desert Medicine Research Centre, New Pali Road, Jodhpur 342 005, India Telephone: +91-291-2744616

E-mail:mbsgh@yahoo.com
Bhatinda had 60 and 140 households of Raika community respectively. Sample size was calculated as 20 percent of the Raika household's population which comes around 40 households.

A preliminary survey was conducted in Raika community. Raika communities are living in and around the Jodhpur city. The studies have been carried out in two villages' viz. Mongra (Khurd and Kalan) and Bhatinda of Jodhpur district, Rajasthan. Simple random technique was adopted for selection of Raika households in two villages (Moser and Kelton, 1964). The data were collected from 40 households of Raika community compri-sing of 258 individuals. At household level, head of the household was interviewed regarding two aspects i.e. demographic and general information regarding possession of camel along with the usage of camel milk. Besides the head of the households, all individual family members of these households were interviewed regarding the consumption of camel milk.

\section{RESULTS AND DISCUSSION}

Analysis of data at household (HH) level revealed that majority of head of households was illiterate $(62.5 \%)$, and engaged in unskilled and semiskilled occupation $(82.5 \%)$. Nuclear and joint families were 45 and 47.5 percent respectively. Average family size was observed 6.45.

Majority of Raika households did not posses 
'She Camel' (72.5\%), hence did not milch the 'She Camel'. In this community, 92.5 percent were of the opinion that camel milk can be stored for sometime but cannot be used for preparation of curd/cheese. Raw and boiled milk can be stored for 4 to 8 hours in their opinion (59.5 and $45.9 \%$ respectively). Most of them (89.5\%) informed that camel milk tastes bitter on long storage. 87.5 percent opined that camel milk can be used for preparation of tea.

Data analysis at individual level revealed that there were 258 individuals in 40 households out of which 50 percent were males. 81 individuals were not available at the time of survey. Regarding consumption of camel milk, 39 percent were using camel milk, whereas, 38.4 percent use it occasionally i.e. once in year or at some occasions. 22.6 percent did not consume camel milk. (Table 1).

In consumers, majority of camel milk users were males $(60.8 \%)$ and belonged to mainly two age groups i.e. above 19 years $(54.8 \%)$ and 10 to 18 years $(23.8 \%)$ as shown in table 2 . In consumers, 47.8 percent were using camel milk daily, whereas, 44.9 percent used once in 15 days or in a month. Quantity of camel milk consumed by majority of consumers $(53.9 \%)$ was ranging from $50 \mathrm{ml}$ to $200 \mathrm{ml}$. Raw milk and boiled milk were consumed by 58.9 and 29.9 percent individuals respectively (Table 3-4).

Table 1: Distribution of individuals according to consumption of camel milk

$(\mathrm{N}=40 \mathrm{HH}$, Total individuals $=258,81$ individuals were not available at the time of survey)

\begin{tabular}{llcc}
\hline S.No. & Response & No of individuals & $\%$ \\
\hline 1 & Yes & 69 & 39.0 \\
2 & Occasionally & & \\
& (once in years or & & \\
& at some occasion) & 68 & 38.4 \\
3 & No & 40 & 22.6 \\
\hline & Total & 177 & 100.0 \\
\hline
\end{tabular}

Table 2: Distribution of consumers according to age groups and sex

\begin{tabular}{|c|c|c|c|c|c|}
\hline \multirow{2}{*}{$\begin{array}{l}S . \\
\text { No. }\end{array}$} & \multirow{2}{*}{$\begin{array}{l}\text { Age groups } \\
\text { (in years) } \\
\end{array}$} & \multicolumn{2}{|c|}{ Males } & \multicolumn{2}{|c|}{ Females } \\
\hline & & $\begin{array}{l}\text { No. of } \\
\text { idividuals }\end{array}$ & $\%$ & $\begin{array}{c}\text { No. of } \\
\text { individuals }\end{array}$ & $\%$ \\
\hline 1 & $0-1$ & - & - & - & - \\
\hline 2 & $1-5$ & 6 & 14.2 & 3 & 11.1 \\
\hline 3 & $6-9$ & 3 & 7.2 & 5 & 18.5 \\
\hline 4 & $10-18$ & 10 & 23.8 & 5 & 18.5 \\
\hline \multirow[t]{2}{*}{5} & 19 and above & 23 & 54.8 & 14 & 51.9 \\
\hline & Total & 42 & 100.0 & 27 & 100.0 \\
\hline
\end{tabular}

Regarding usage of other milk by Raika community, 77 percent of individuals were using goat milk, whereas, 3.5 percent also used sheep milk. No individuals were found to be suffering from any chronic disease, especially diabetes at the time of survey. Only 0.6 percent showed the symptoms of diabetes i.e. polyurea, polydepsia and polypepsia. (Tables 5).

Nearly 27 percent of the Raika community kept She - camel but consumption of camel milk by the Raika community was less $(18.6 \%)$ and consuming low quantity. No individual was found to be suffering from Diabetes whether they were consuming or not consumming camel milk and observed almost negligible $(0.6 \%)$ symptoms of diabetes i.e. polyurea, polydepsia and polypepsia. Still there is a dilemma demanding more research work in this direction.

Table 3: Distribution of consumers according to frequency of consumption of camel milk

\begin{tabular}{llcr}
\hline $\begin{array}{l}\text { S. } \\
\text { No. } \begin{array}{l}\text { Frequency of } \\
\text { consumption } \\
\text { of camel milk }\end{array}\end{array}$ & $\begin{array}{c}\text { No of } \\
\text { individuals }\end{array}$ & $\%$ \\
\hline 1 & Daily & 33 & 47.8 \\
2 & Once in 1 - 3 days & 2 & 2.9 \\
3 & Once in 3 - 7 days & 3 & 4.3 \\
4 & Once in 15 days & 13 & 18.8 \\
5 & Once in month & 18 & 26.1 \\
\hline & Total & 69 & 100.0 \\
\hline
\end{tabular}

Table 4: Distribution of consumers according to quantity of consumption of camel milk

\begin{tabular}{llcr}
\hline $\begin{array}{l}\text { S. } \\
\text { No. }\end{array}$ & $\begin{array}{c}\text { Quantity of } \\
\text { consumption of } \\
\text { camel milk }\end{array}$ & $\begin{array}{c}\text { No of } \\
\text { individuals }\end{array}$ & $\%$ \\
\hline 1 & Less than $50 \mathrm{ml}$ & 3 & 4.6 \\
2 & $50-100 \mathrm{ml}$ & 15 & 23.1 \\
3 & $100-200 \mathrm{ml}$ & 20 & 30.8 \\
4 & $200-300 \mathrm{ml}$ & 10 & 15.4 \\
5 & $300-400 \mathrm{ml}$ & 2 & 3.1 \\
6 & $400-500 \mathrm{ml}$ & 10 & 15.4 \\
7 & More than $500 \mathrm{ml}$ & 5 & 7.6 \\
\hline & Total & 65 & 100.0 \\
\hline
\end{tabular}

Table 5: Distribution of individuals according to symptoms of diabetes

\begin{tabular}{|c|c|c|c|c|c|}
\hline \multirow{2}{*}{$\begin{array}{l}\text { S. } \\
\text { No }\end{array}$} & \multirow{2}{*}{$\begin{array}{l}\text { Symptoms of } \\
\text { Diabetes }\end{array}$} & \multicolumn{2}{|c|}{ Yes } & \multicolumn{2}{|c|}{ No } \\
\hline & & $\begin{array}{c}\text { No of } \\
\text { individuals }\end{array}$ & $\%$ & $\begin{array}{c}\text { No of } \\
\text { individuals }\end{array}$ & $\%$ \\
\hline 1 & Polyurea & 1 & 0.6 & 173 & 99.4 \\
\hline 2 & Polydepsia & 1 & 0.6 & 173 & 99.4 \\
\hline 3 & Polypepsia & 1 & 0.6 & 173 & 99.4 \\
\hline
\end{tabular}




\section{ACKNOWLEDGEMENTS}

The author is grateful to Director, Desert Medicine Research Center, Jodhpur, for guidance and facilities provided during the studies.

\section{REFERENCES}

Agarwal et al, 2003. "Effect of camel milk on glycemic control, lipid profile and diabetes quality of life in type diabeters: A randomized prospective controlled cross over study." Indian J. Anim. Sci., 73(10): 11051110 .

Bhasker News from Bikaner. 2003. "Effect of She camel's milk: Raika caste community Does not suffer suffer from Diabetes", 31 $31^{\text {st }}$ January, 2003.

Breitling, Lutz. 2002. Insulin and anti-diabetes activity of camel milk. Journal of Camel Practice and Research, 9: 43-45.

Moser S.C. and G. Kalton. 1964. Survey Methods in Social Investigations. $2^{\text {nd }} \mathrm{Ed}$. London: Heinemann educational Books Ltd. and English Book Society.

World Health Organization. 1999. Management of Severe Malnutrition: A Manual For Physicians and Other Senior Health Workers. Geneva: WHO. 